\title{
Clinical Features and Outcomes of Patients With Chronic Myeloid Leukemia Presenting With Isolated Thrombocytosis: A Systematic Review and a Case From Our Institution
}

\author{
Dawood Findakly ${ }^{1}$, Waqas Arslan ${ }^{2,3}$ \\ 1. Internal Medicine, Creighton University Arizona Health Education Alliance/Valleywise Health Medical Center, \\ Phoenix, USA 2. Hematology and Oncology, Creighton University Arizona Health Education Alliance/Valleywise Health \\ Medical Center, Phoenix, USA 3. Hematology and Oncology, Creighton University Maricopa Medical Center, Phoenix, \\ USA
}

Corresponding author: Dawood Findakly, dawood_findakly@yahoo.com

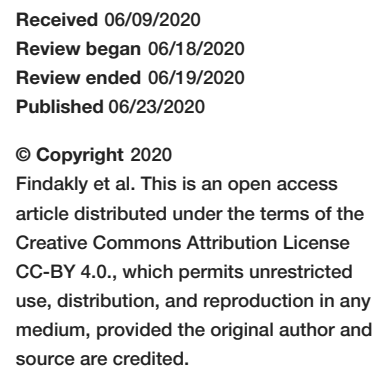

Review began 06/18/2020

() Copyright 2020

Findakly et al. This is an open access article distributed under the terms of the CC-BY 4.0, which permits unrestricted use, distribution, and reproduction in any source are credited.

\begin{abstract}
Chronic myeloid leukemia (CML) represents a common condition in the spectrum of myeloproliferative disorders (MPD). It classically exhibits leukocytosis, but rarely presents with isolated thrombocytosis. This paper is designed to review the clinicopathologic features, treatment, and outcomes of patients with CML who present with isolated thrombocytosis.
\end{abstract}

We searched PubMed, MEDLINE ${ }^{\circledR}$, ScienceDirect, and Scopus for English-language articles about case series and case reports for the period 2000-2020 with the terms "chronic myeloid leukemia" and "thrombocytosis" and pooled them with a case from our institution. Cases were also incorporated from the reference list and screened for inclusion. A total of 20 cases were included in the final cohort. The male-to-female ratio was $1: 1.86$. The mean age of the patients at the time of initial diagnosis was 40.5 years (range: $9-77$ years). Out of 17 cases with available data, seven (41\%) were asymptomatic and found to have thrombocytosis incidentally upon routine blood work. Five cases (29.4\%) either had a history of thrombotic events or presented with severe thrombotic complications, including ischemic cerebrovascular accidents (CVA), myocardial infarction (MI), pulmonary embolism (PE), and/or miscarriages. Four cases (23.5\%) had more than one symptom at presentation, including headache, syncope, and bruising. The average platelet count was $1,923 \times 10^{9} / \mathrm{L}$ (range: $584-8,688 \times 10^{9} / \mathrm{L}$ ), and one case $(5 \%)$ had anemia. The bone marrow (BM) examination showed normal cellularity and normal myeloid to erythroid (M/E) ratio in seven (50\%) and $11(84.6 \%)$ out of the 14 and 13 cases with reported data, respectively. Moreover, megakaryocytes in the BM were small in 10 cases (71.4\%), pleomorphic in three cases (21.4\%), and dysplastic in one case (7.1\%).

Accurate differentiation among MPD subtypes and the exclusion of CML is critical in reaching a proper diagnosis to decide on proper therapy and eventually modify outcomes. Prompt evaluation for the precise diagnosis of patients presenting with isolated marked thrombocytosis will help expedite their diagnosis and initiation of a specific tyrosine kinase inhibitor (TKI) therapy, thereby promptly inducing remission, preventing thrombotic complications, and avoiding adverse drug events, which would eventually improve outcomes.

Categories: Genetics, Internal Medicine, Hematology

Keywords: isolated thrombocytosis, bcr-abl positive, chronic myeloid leukemia, systematic review

\section{Introduction And Background}

Chronic myeloid leukemia (CML) belongs to the spectrum of myeloproliferative disorders (MPD), which are myeloid lineage clonal disorders that also include essential thrombocythemia, polycythemia vera, and myelofibrosis [1]. It accounts for 15-20\% of all adult leukemia cases, with an estimated incidence of fewer than 5,000 new cases in the United States per year [2,3]. CML is characterized by the excess of white blood cells (WBCs) resulting from the uncontrolled proliferation of mature granulocytes and their precursors [3]. When patients present with isolated thrombocytosis, testing for the Philadelphia chromosome or BCR-ABL is essential to identify CML cases among them [4]. This study reviews the clinical characteristics, diagnosis, therapeutic modalities, and prognosis regarding patients with isolated thrombocytosis as an initial presentation of CML.

\section{Review}

\section{Aim of the study}

This review aimed to investigate the available published data on the clinical characteristics, treatment, and prognosis of CML in patients presenting with isolated thrombocytosis. 
Patients and methods

Literature Search Strategy

We performed a systematic review of the PubMed, MEDLINE ${ }^{\circledR}$, ScienceDirect, and Scopus databases for the published literature in the English language during the period 2000-2020 that reported isolated thrombocytosis as an initial presentation in laboratory-confirmed CML patients. The recognized list of cases and abstracts were evaluated for any additional articles of interest from reference lists and pooled with a case from our institution (Figure 1).

Data Extraction and Statistical Analysis

We extracted data, when available, on age at the time of diagnosis, peripheral blood (PB) and bone marrow (BM) examination findings, splenic enlargement, diagnosis, treatment, complications, duration of followups, and outcomes. One case from our institution was also included in our analysis. The pooled data were interpreted and summarized through descriptive statistics using central tendency and dispersion measures.

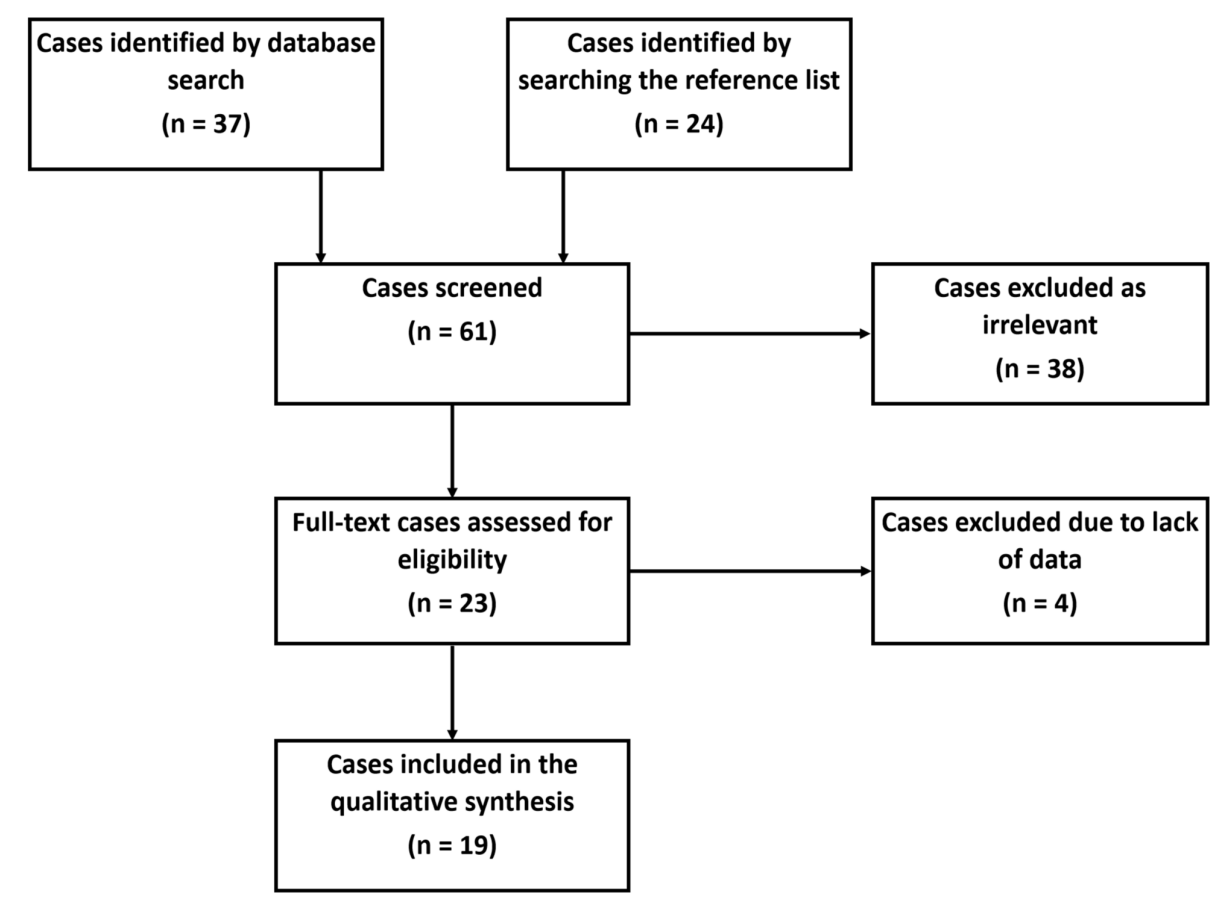

FIGURE 1: The PRISMA flow diagram detailing the cases of CML that presented with isolated thrombocytosis

PRISMA: Preferred Reporting Items for Systematic Reviews and Meta-Analyses; CML: chronic myeloid leukemia

\section{Results}

We recognized 19 published studies where CML diagnosis was established in the setting of isolated thrombocytosis. Furthermore, we included one case from our institutional database. The final cohort consisted of a total of 20 patients with CML who presented with isolated thrombocytosis. The demographics, clinical features, and outcomes of the 20 cases are summarized in Table 1 [5-19]. The mean age at diagnosis was 40.5 years (range: 9-77 years), with 15 (75\%) being 60 years of age or younger at the time of initial diagnosis. The final data consisted of seven males and 13 females (male-to-female ratio: 1:1.86). Age and gender distribution of patients are summarized in Figure 2.

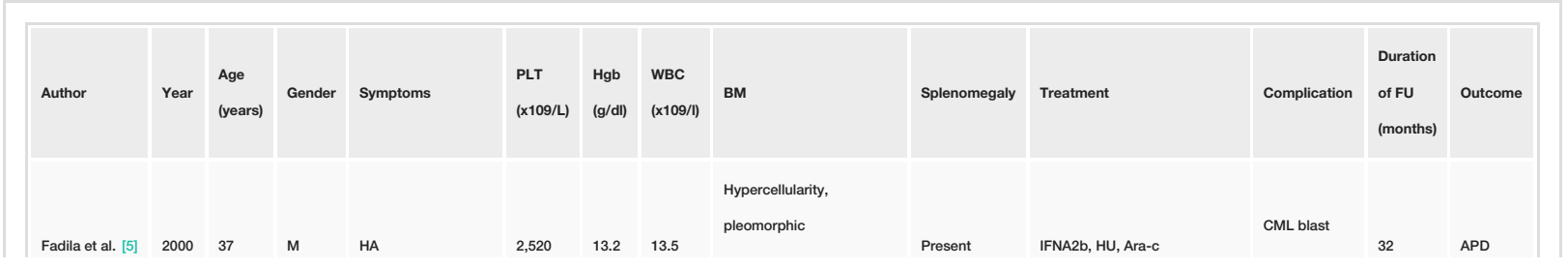




\section{Cureus}

\begin{tabular}{|c|c|c|c|c|c|c|c|c|c|c|c|c|c|}
\hline & & & & & & & & $\begin{array}{l}\text { megakaryocytic, normal } \\
\text { M:E ratio }\end{array}$ & & & phase & & \\
\hline $\begin{array}{l}\text { Damaj, et al. } \\
\text { [6] }\end{array}$ & 2002 & 28 & $\mathrm{~F}$ & NM & 1,723 & 13.3 & 12.9 & NM & NM & $\mathrm{HU}$ & NM & 72 & AIN \\
\hline $\begin{array}{l}\text { Michiels et al. } \\
\text { [7] }\end{array}$ & 2003 & 65 & $\mathrm{~F}$ & Asymptomatic & 584 & 12.4 & 4.3 & $\begin{array}{l}\text { Normal cellularity, small } \\
\text { megakaryocytes, normal } \\
\text { M:E ratio }\end{array}$ & Absent & $\mathrm{HU}$ & NM & 144 & AIN \\
\hline $\begin{array}{l}\text { Girodon et al. } \\
{[8]}\end{array}$ & 2005 & 52 & M & $\begin{array}{l}\text { Asymptomatic, } \\
\text { blood donor }\end{array}$ & 672 & 12.9 & 7.9 & $\begin{array}{l}\text { Hypercellularity, small } \\
\text { megakaryocytes, normal } \\
\text { M:E ratio }\end{array}$ & Absent & Imatinib & NM & 7 & AIN \\
\hline Rice et al. [9] & 2005 & 27 & $\mathrm{~F}$ & $\begin{array}{l}\text { Miscarriage, CVA, } \\
\mathrm{PE}\end{array}$ & 1,880 & 14 & 8.4 & NM & Absent & $\begin{array}{l}\text { Anagrelide, HU, imatinib, } \\
\text { PLTP, SCT }\end{array}$ & CVA & 48 & APD \\
\hline Rice et al. [9] & 2005 & 42 & $\mathrm{~F}$ & Asymptomatic & 700 & WNL & WNL & NM & Absent & $\begin{array}{l}\text { Anagrelide, } \mathrm{HU} \text {, imatinib, } \\
\text { steroids, SCT }\end{array}$ & CAD & 36 & $\begin{array}{l}\text { DOD } \\
\text { (GVHD) }\end{array}$ \\
\hline $\begin{array}{l}\text { Breccia et al. } \\
\text { [10] }\end{array}$ & 2008 & 43 & M & Asymptomatic & 1,310 & 14 & 2.8 & $\begin{array}{l}\text { Normal cellularity, } \\
\text { dysplastic } \\
\text { megakaryocytes, M:E } \\
\text { ratio, NM }\end{array}$ & NM & $\begin{array}{l}\mathrm{HU}(\mathrm{R}) \text {, then switched to } \\
\text { imatinib }\end{array}$ & Leukopenia & 15 & AIN \\
\hline $\begin{array}{l}\text { Niekerk et al. } \\
\text { [11] }\end{array}$ & 2012 & 68 & $\mathrm{~F}$ & $\begin{array}{l}\text { Asymptomatic, } \mathrm{h} / \mathrm{o} \\
\text { follicular Iymphoma }\end{array}$ & 2,062 & WNL & WNL & $\begin{array}{l}\text { Hypercellularity, small } \\
\text { megakaryocytes, high M:E } \\
\text { ratio }\end{array}$ & NM & $\begin{array}{l}\text { TKI (intol.), then switched to } \\
\text { peg-IFNa-2a }\end{array}$ & $\begin{array}{l}\text { TKl intol.: } \\
\text { acrocyanosis, } \\
\text { dyspnea }\end{array}$ & 9 & AIN \\
\hline Byun et al. [4] & 2014 & 21 & $\mathrm{~F}$ & $\begin{array}{l}\text { Abdominal pain } \\
\text { (ruptured corpus } \\
\text { luteal cyst) }\end{array}$ & 3,777 & 10.1 & 10 & $\begin{array}{l}\text { Hypercellularity, small } \\
\text { megakaryocytes, high M:E } \\
\text { ratio }\end{array}$ & Absent & $\begin{array}{l}\mathrm{HU}(\mathrm{R}) \text {, then switched to } \\
\text { imatinib }\end{array}$ & NM & 3 & AIN \\
\hline $\begin{array}{l}\text { Ebrahem et al. } \\
\text { [12] }\end{array}$ & 2015 & 39 & $\mathrm{~F}$ & $\begin{array}{l}\text { Syncope, seizure, } \\
\text { MI }\end{array}$ & 2,500 & WNL & 13.8 & NM & Present & Dasatinib, PLTP & NM & NM & AIN \\
\hline $\begin{array}{l}\text { Yilmaz et al. } \\
{[13]}\end{array}$ & 2016 & 77 & $\mathrm{~F}$ & $\begin{array}{l}\text { Asymptomatic, h/o } \\
\text { CVA }\end{array}$ & 711 & 13.8 & 5.2 & $\begin{array}{l}\text { Normal cellularity, small } \\
\text { megakaryocytes, normal } \\
\text { M:E ratio }\end{array}$ & Absent & Imatinib & NM & 3 & AIN \\
\hline $\begin{array}{l}\text { Yilmaz et al. } \\
\text { [13] }\end{array}$ & 2016 & 70 & $\mathrm{~F}$ & $\begin{array}{l}\text { Asymptomatic, h/o } \\
\text { CVA, MI }\end{array}$ & 1,853 & 13 & 9.2 & $\begin{array}{l}\text { Normal cellularity, small } \\
\text { megakaryocytes, normal } \\
\text { M:E ratio }\end{array}$ & Absent & Imatinib & NM & 12 & AIN \\
\hline $\begin{array}{l}\text { Yilmaz et al. } \\
\text { [13] }\end{array}$ & 2016 & 30 & M & Flu-like & 1,277 & 15.7 & 11.1 & $\begin{array}{l}\text { Hypercellularity, small } \\
\text { megakaryocytes, normal } \\
\text { M:E ratio }\end{array}$ & Absent & $\begin{array}{l}\text { Imatinib }(\mathrm{R}) \text {, then switched to } \\
\text { nilotinib }(\mathrm{R}) \text {, then switched to } \\
\text { dasatinib }(\mathrm{R}) \text {, pending SCT }\end{array}$ & NM & 12 & APD \\
\hline $\begin{array}{l}\text { Boklan et al. } \\
{[14]}\end{array}$ & 2017 & 10 & M & Bruising & 8,688 & 11.2 & WNL & $\begin{array}{l}\text { Hypercellularity, } \\
\text { pleomorphic } \\
\text { megakaryocytic, normal } \\
\text { M:E ratio }\end{array}$ & Absent & $\begin{array}{l}\text { PLTP, HU, imatinib (intol.), } \\
\text { then switched to dasatinib }\end{array}$ & $\begin{array}{l}\text { TKI intol.: } \\
\text { acrocyanosis, } \\
\text { dyspnea }\end{array}$ & 5 & AIN \\
\hline Huho et al. [15] & 2018 & 9 & M & $\begin{array}{l}\text { Cough, fatigue, HA, } \\
\text { bruising }\end{array}$ & 2,500 & 13 & 8 & $\begin{array}{l}\text { Normal cellularity, small } \\
\text { megakaryocytes, normal } \\
\text { M:E ratio }\end{array}$ & Absent & Dasatinib & NM & 9 & AIN \\
\hline $\begin{array}{l}\text { Soliman et al. } \\
{[16]}\end{array}$ & 2019 & 46 & M & $\begin{array}{l}\text { Chest pain, } \\
\text { dyspnea }\end{array}$ & 1,065 & 11.7 & 6.7 & $\begin{array}{l}\text { Normal cellularity, small } \\
\text { megakaryocytes, normal } \\
\text { M:E ratio }\end{array}$ & Absent & Dasatinib & NM & 24 & AIN \\
\hline $\begin{array}{l}\text { Aslan et al. } \\
\text { [17] }\end{array}$ & 2019 & 25 & $\mathrm{~F}$ & NM & 678 & WNL & WNL & NM & NM & Imatinib & Leukopenia & 3 & AIN \\
\hline $\begin{array}{l}\text { Aslan et al. } \\
{[17]}\end{array}$ & 2019 & 40 & $\mathrm{~F}$ & NM & 747 & WNL & 8.8 & NM & NM & Imatinib & NM & 3 & AIN \\
\hline Han et al. [18] & 2020 & 61 & $\mathrm{~F}$ & $\begin{array}{l}\text { Liver mass } \\
\text { (adenocarcinoma) }\end{array}$ & 2,464 & 11.1 & 7 & $\begin{array}{l}\text { Hypercellularity, } \\
\text { pleomorphic } \\
\text { megakaryocytic, normal } \\
\text { M:E ratio }\end{array}$ & Absent & HU, imatinib & NM & 6.5 & DUR \\
\hline Findakly and & & & & & & & & Normal cellularity, small & & & & & \\
\hline
\end{tabular}




\section{Cureus}

Arslan [ $13.3 \quad 7.2$

megakaryoch

TABLE 1: Summary of the available publications (including our case) regarding CML patients who present with isolated thrombocytosis

M: male; F: female; HA: headache; NM: not mentioned; CVA: cerebrovascular accident; PE: pulmonary embolism; h/o: history of; MI: myocardia infarction; WNL: within normal limits; PLT: platelet count; Hgb: hemoglobin; WBC: white blood cells; BM: bone marrow; M:E ratio: myeloid-toerythroid ratio; IFNA2b: interferon-alpha 2b; HU: hydroxyurea; Ara-c: cytosine arabinoside; PLTP: plateletpheresis; SCT: stem cell transplant; R: refractory; intol.: intolerance; TKI: tyrosine kinase inhibitor; peg-IFNa-2a: pegylated-interferon alpha-2a; CML: chronic myeloid leukemia; CAD: coronary artery disease; FU: follow-up; APD: alive, persistent disease; AIN: alive, in remission; DOD: died of disease; GVHD: graft-versus-host disease; DUR: died of unknown reason

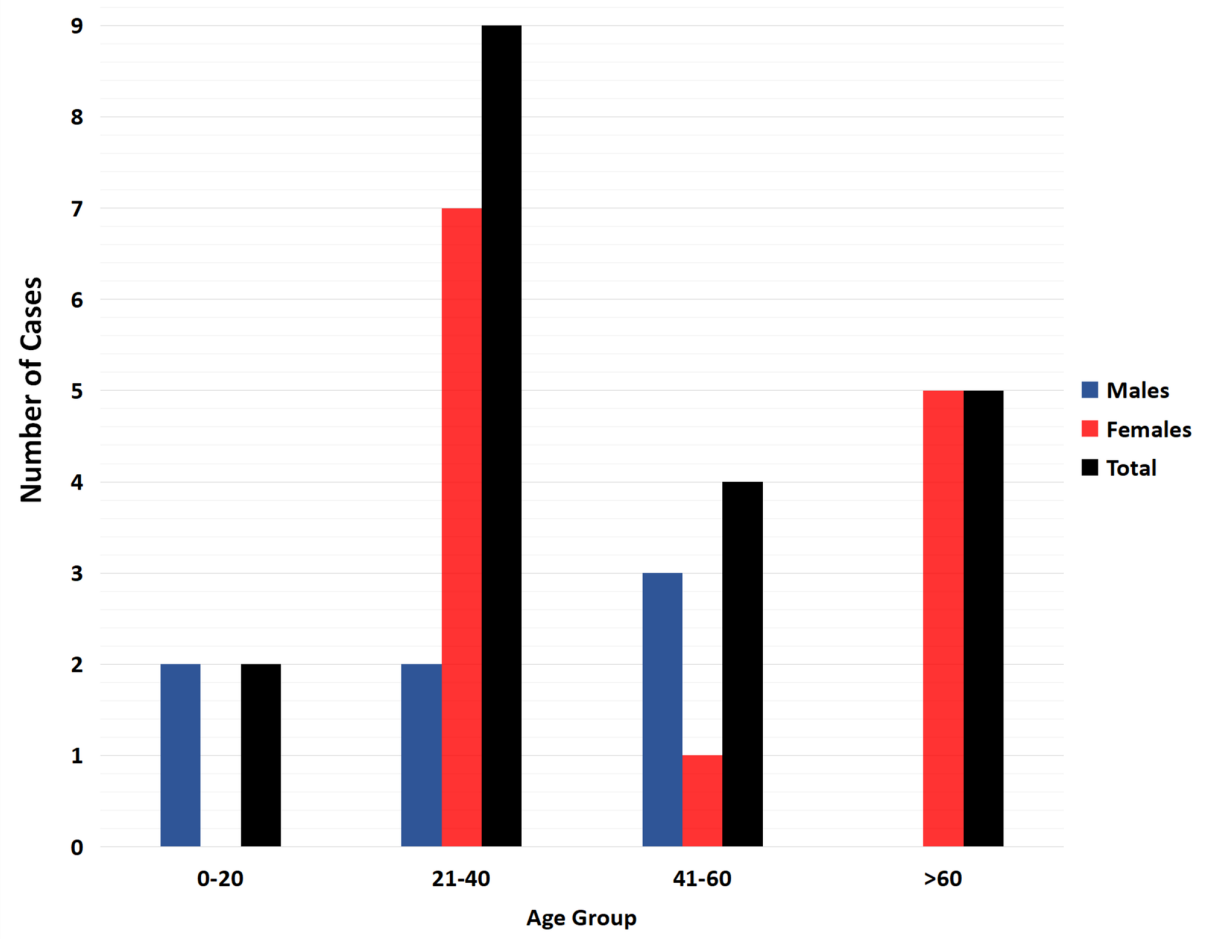

FIGURE 2: Age and gender distribution of CML patients presenting with isolated thrombocytosis

The bar graph represents the number of patients with $C M L$ for the specific age and gender group

CML: chronic myeloid leukemia

Among patients with reported data, all (100\%) reported being tested negative for the Janus kinase 2 (JAK2), calreticulin (CALR), and thrombopoietin receptor (MPL) gene mutations. Moreover, all (100\%) tested positive for BCR-ABL translocation and, therefore, was diagnosed with chronic-phase CML. Moreover, out of the 15 patients with available data describing splenomegaly, either upon physical examination or imaging, only two $(13.3 \%$ ) had splenomegaly, while it was absent in the 13 patients (86.7\%). The average platelet count was $1,923 \times 10^{9} / \mathrm{L}$ (range; $584-8,688 \times 10^{9} / \mathrm{L}$ ). Only one patient $(5 \%)$ reported anemia with a hemoglobin level of $10.1 \mathrm{~g} / \mathrm{dl}$. The patients' characteristics are summarized in Table 2. 


\section{Cureus}

\begin{tabular}{|l|l|}
\hline Patient characteristics & Value \\
\hline Patients $(\mathrm{n})$ & 20 \\
Gender (M/F) & $7 / 13$ \\
Age (years), mean (range) & $40.5(9-77)$ \\
PLT (x10 $/ \mathrm{L})$, mean (range) & $1,923(584-8,688)$ \\
WBC count (x109/L), mean (range) & $8.2(2.8-13.89)$ \\
Hgb (g/dl), mean (range) & $12.8(10.1-15.7)$ \\
Splenomegaly (n, \%) & $2,13.3 \%$ \\
\hline
\end{tabular}

\section{TABLE 2: Patient characteristics}

n: number; M: male; F: female; PLT: platelet count; WBC: white blood cells; Hgb: hemoglobin

Data on BM characteristics were reported for 14 patients. Interestingly, a peculiarly normal cellularity and myeloid-to-erythroid (M:E) ratio was reported in seven (50\%) and 11 (84.6\%) out of the 14 and 13 patients with reported data, respectively. Moreover, megakaryocytes were small in 10 patients (71.4\%), pleomorphic in three patients (21.4\%), and dysplastic in a single patient (7.1\%), respectively. Nineteen patients (95\%) were in a chronic CML phase. The case from our institution tested negative for BCR-ABL gene mutation in $\mathrm{PB}$, but subsequent BM aspiration and biopsy performed later were consistent with CML.

In terms of treatment modalities, hydroxyurea $(\mathrm{HU})$ was used as part of initial therapy in nine patients (45\%), out of which four (44\%) received it solely; two (22\%) were noticed to have a refractory thrombocytosis and, therefore, were switched to tyrosine kinase inhibitor (TKI) therapy. TKI therapy was used in 17 patients (85\%), out of which nine patients (53\%) received it solely. Fifteen patients (88\%) were treated with a single TKI, one patient (6\%) was treated with two TKIs, and another patient (6\%) was treated with more than two TKIs given refractory disease. The initial TKI therapy was imatinib and dasatinib in 12 (75\%) and four (25\%) of the 16 cases that specifically reported the name of the TKI medication used. Furthermore, three patients (15\%) received plateletpheresis as part of the treatment, and four patients (25\%) were enrolled for stem cell transplantation (SCT).

The mean duration of follow-up was 25 months (range 3-144 months). Complications during therapy were reported in seven cases (35\%), where one case (5\%) progressed to the blastic-phase CML, two female patients (10\%) developed significant thrombotic complications despite being on HU, two (10\%) developed leukopenia, and two (10\%) had TKI-intolerance out of which one reported to develop acrocyanosis and dyspnea. Notably, thrombotic complications occurred after diagnosis with two female patients (100\%) being treated with HU preceding imatinib therapy. Furthermore, five (38.4\%) out of the 13 female patients had previously had and/or developed major thrombotic events, including cerebrovascular accident (CVA), myocardial infarction (MI), coronary artery disease (CAD), pulmonary embolism (PE), and miscarriage; those patients had a mean age of 51 years (range: $27-77$ years).

In terms of outcomes, 15 patients (75\%) were alive and in remission at the time of follow-up, three patients (15\%) were alive with persistent disease, and two had died (10\%). Both (100\%) deaths had occurred during the chronic CML phase; the first patient (5\%) had died of a complication of the SCT where the patient had developed graft versus host disease (GVHD), and the second patient (5\%) had died of an obscure reason. Moreover, both had been females with a mean age of 51.5 years (range: $42-61$ years), and death had occurred at a mean duration of follow-up of 21 months (range: 6.5-36 months) (Table 3). 


\section{Cureus}

\begin{tabular}{|l|l|}
\hline Patient outcomes & $\mathbf{N}, \%$ \\
\hline AIR & $15,75 \%$ \\
APD & $3,15 \%$ \\
Deceased & $2,10 \%$ \\
\hline
\end{tabular}

\section{TABLE 3: Summary of patient outcomes}

$\mathrm{N}$ : number; AIR: alive, in remission; APD: alive, with persistent disease

\section{Discussion}

In our cohort, several findings are noteworthy. First, Upon PB examination, the average platelet count was $1,923 \times 10^{9} / \mathrm{L}$ (range: $584-8,688 \times 10^{9} / \mathrm{L}$ ). Second, unlike classical CML, splenomegaly was present in only about $13 \%$, while normal BM cellularity and M:E ratio were noted in $50 \%$ and approximately $85 \%$ of patients with reported data, respectively. Third, female patients had worse morbidity and mortality rates compared to male patients. Nearly $38 \%$ of the female patients had previously had and/or developed major thrombotic events with a mean age of 51 years (range: $27-77$ years).

Typical PB smear features of CML include marked leukocytosis due to neutrophils being in all maturation stages, with a WBC count ranging between $12-1,000 \times 10^{9} / \mathrm{L}$ [20]. The typical platelet count at diagnosis in CML could vary from normal range to less than $1,000 \times 10^{9} / \mathrm{L}$ [1]. Although thrombocytosis is a relatively common presenting feature, it rarely exceeds $1,000 \times 10^{9} / \mathrm{L}$. Moreover, the typical BM aspirate findings for patients with CML include hyperplasia of granulocytic progenitor cells with markedly elevated M:E ratio contributing to hypercellularity of BM. Other non-specific BM findings constitute an increase in vascularity and reticulin fibrosis [21]. Moreover, the number and size of erythroid lineage are decreased, and the megakaryocytes are distinguished by being smaller than normal with nuclei that are characteristically hypolobulated [22].

Regarding modalities of therapy, $\mathrm{HU}$ is an antimetabolite that acts by reducing the platelet count in patients with essential thrombocythemia and also aids in preventing thrombosis. Moreover, imatinib, nilotinib, and dasatinib were reported as treatment modalities in cases included in this review. Of those, nilotinib and dasatinib are second-generation TKI medications with superior efficacy and higher potency compared to imatinib as a first-line treatment for the chronic-phase CML and cases with resistance or intolerance to prior TKI therapy [23,24]. False-negative results may occur due to poor quality or failure to promptly stabilize RNA sample at the time of sample collection, leading to a failure of the polymerase chain reaction (PCR), atypical transcripts, or during therapeutic monitoring [25-27].

The initial PB fluorescence in-situ hybridization (FISH) testing for the patient we included from our institution was negative for the BCR-ABL gene mutation. However, consequent BM aspiration and biopsy performed as platelet count continued to rise was consistent with CML. Therefore, we underscore the importance of providers routinely pursuing genetic testing for the BCR/ABL gene in both $\mathrm{PB}$ and $\mathrm{BM}$ as part of the workup for patients with isolated thrombocytosis to avoid misdiagnosis or delayed diagnosis of CML in this patient population.

\section{Conclusions}

Our study illustrates that CML is a vital differential that should not be missed, particularly among patients with isolated marked thrombocytosis. Pursuing genetic testing for the BCR/ABL fusion gene in both PB and $\mathrm{BM}$ is essential in the diagnosis. Familiarity with this entity will help to promptly identify it, expedite proper diagnosis, and subsequently initiate specific TKI therapy that will help induce remission, prevent thrombotic complications, and avoid adverse drug events.

\section{Additional Information}

\section{Disclosures}

Conflicts of interest: In compliance with the ICMJE uniform disclosure form, all authors declare the following: Payment/services info: All authors have declared that no financial support was received from any organization for the submitted work. Financial relationships: All authors have declared that they have no financial relationships at present or within the previous three years with any organizations that might have an interest in the submitted work. Other relationships: All authors have declared that there are no other relationships or activities that could appear to have influenced the submitted work. 


\section{References}

1. Choi CW, Bang SM, Jang S, et al.: Guidelines for the management of myeloproliferative neoplasms . Korean J Intern Med. 2015, 30:771-788. 10.3904/kjim.2015.30.6.771

2. Granatowicz A, Piatek CI, Moschiano E, El-Hemaidi I, Armitage JD, Akhtari M: An overview and update of chronic myeloid leukemia for primary care physicians. Korean J Fam Med. 2015, 36:197-202. 10.4082/kjfm.2015.36.5.197

3. Galinsky I, Buchanan S: Guide to interpreting disease responses in chronic myeloid leukemia . J Adv Pract Oncol. 2012, 3:225-236. 10.6004/jadpro.2012.3.4.3

4. Byun YJ, Park BB, Lee ES, Choi KS, Lee DS: A case of chronic myeloid leukemia with features of essential thrombocythemia in peripheral blood and bone marrow. Blood Res. 2014, 49:127-129. 10.5045/br.2014.49.2.127

5. Fadilah SA, Cheong SK: BCR-ABL positive essential thrombocythaemia: a variant of chronic myelogenous leukaemia or a distinct clinical entity: a special case report. Singapore Med J. 2000, 41:595-598.

6. Damaj G, Delabesse E, Le Bihan C, et al.: Typical essential thrombocythaemia does not express BCR-Abelson fusion transcript. Br J Haematol. 2002, 116:812-816. 10.1046/j.0007-1048.2002.03343.x

7. Michiels JJ, Berneman Z, Schroyens W, et al.: Philadelphia ( $\mathrm{Ph}$ ) chromosome-positive thrombocythemia without features of chronic myeloid leukemia in peripheral blood: natural history and diagnostic differentiation from Ph-negative essential thrombocythemia. Ann Hematol. 2004, 83:504-512. 10.1007/s00277-004-0877-4

8. Girodon F, Bailly F, Barry M, et al.: Philadelphia chromosome-positive thrombocythemia without features of chronic myeloid leukemia (CML) in peripheral blood. Ann Hematol. 2005, 84:409-410. 10.1007/s00277-0040993-1

9. Rice L, Popat U: Every case of essential thrombocythemia should be tested for the Philadelphia chromosome. Am J Hematol. 2005, 78:71-73. 10.1002/ajh.20257

10. Breccia M, Cannella L, Diverio D, et al.: Isolated thrombocytosis as first sign of chronic myeloid leukemia with e6a2 BCR/ABL fusion transcript, JAK2 negativity and complete response to imatinib. Leuk Res. 2008, 32:177-180. 10.1016/i.leukres.2007.05.022

11. van Kooten Niekerk PB, Roug AS, Nederby L, et al.: Chronic myeloid leukemia presenting with isolated thrombocythemia: a case revealing its stem cell biology. Blood. 2012, 120:4427. 10.1182/blood.V120.21.4427.4427

12. Ebrahem R, Ahmed B, Kadhem S, Truong Q: Chronic myeloid leukemia: a case of extreme thrombocytosis causing syncope and myocardial infarction. Cureus. 2016, 8:e476. 10.7759/cureus.476

13. Yilmaz M, Guvercin B, Konca C: Cases of chronic myeloid leukemia presenting with isolated thrombocytosis: case reports and review of the literature. Int J Clin Exp Med. 2016, 9:8799-8802.

14. Boklan JL, Walsh AM, de la Maza MC, Su LL, Nizzi FA Jr, Schafernak KT: Pediatric chronic myeloid leukemia presenting with extreme thrombocytosis simulating essential thrombocythemia. J Pediatr Hematol Oncol. 2018, 40:456-457. 10.1097/MPH.0000000000001154

15. Huho AN, Issaq N, Iacobas I, Elghetany TM, López-Terrada D, Fisher KE, Punia JN: A rare case of pediatric chronic myelogenous leukemia presenting with severe thrombocytosis without leukocytosis. Pediatr Dev Pathol. 2018, 21:100-104. 10.1177/1093526617698601

16. Soliman DS, Abdulla MA, Sabbagh AA, Akiki S, Ibrahim F, Mustafa A, Yassin M: BCR/ABL-1-positive myeloproliferative neoplasm presenting with isolated remarkable thrombocytosis with atypical clinicopathological features: discussion from management point of view. J Blood Lymph. 2019, 9:243.

17. Aslan V, Iltar U, Ozen N, Göçer M, Çelik M, Kurtoğlu E, Erkal O: Three chronic myeloid leukemia cases that presented like essential thrombocythemia. HemaSphere. 2019, 3:891. 10.1097/01.HS9.0000566340.36375.a0

18. Han P, Han Z, Mao X, et al.: Liver tumor concurrent with chronic myelocytic leukemia and extreme thrombocytosis: a rare case report [PREPRINT]. Diagn Pathol. 2020, 10.21203/rs.3.rs-17513/v1

19. Findakly D, Arslan W: Chronic myeloid leukemia: atypical presentation and diagnostic pitfall in the workup of isolated thrombocytosis. Cureus. 2020, 12:e8498. 10.7759/cureus.8498

20. Cotta CV, Bueso-Ramos CE: New insights into the pathobiology and treatment of chronic myelogenous leukemia. Ann Diagn Pathol. 2007, 11:68-78. 10.1016/j.anndiagpath.2006.12.002

21. Lundberg LG, Lerner R, Sundelin P, Rogers R, Folkman J, Palmblad J: Bone marrow in polycythemia vera, chronic myelocytic leukemia, and myelofibrosis has an increased vascularity. Am J Pathol. 2000, 157:15-19. 10.1016/S0002-9440(10)64511-7

22. Tober J, Koniski A, McGrath KE, et al.: The megakaryocyte lineage originates from hemangioblast precursors and is an integral component both of primitive and of definitive hematopoiesis. Blood. 2007, 109:14331441. 10.1182/blood-2006-06-031898

23. García-Gutiérrez V, Hernández-Boluda JC: Tyrosine kinase inhibitors available for chronic myeloid leukemia: efficacy and safety. Front Oncol. 2019, 9:603. 10.3389/fonc.2019.00603

24. Wei G, Rafiyath S, Liu D: First-line treatment for chronic myeloid leukemia: dasatinib, nilotinib, or imatinib . J Hematol Oncol. 2010, 3:47. 10.1186/1756-8722-3-47

25. Branford S: Chronic myeloid leukemia: molecular monitoring in clinical practice. Hematology Am Soc Hematol Educ Program. 2007, 1:376-383. 10.1182/asheducation-2007.1.376

26. Jabbour E, Kantarjian H: Chronic myeloid leukemia: 2016 update on diagnosis, therapy, and monitoring . Am J Hematol. 2016, 91:252-265. 10.1002/ajh.24275

27. Nashed AL, Rao KW, Gulley ML: Clinical applications of BCR-ABL molecular testing in acute leukemia . J Mol Diagn. 2003, 5:63-72. 10.1016/S1525-1578(10)60454-0 